\title{
"MUITAS COISAS ELES FALAM ERRADO PORQUE TEM ESSA MISTURA DA LÍNGUA ALEMÃ": VOZES DE PROFESSORES SOBRE A EDUCAÇÃO EM CONTEXTOS DE LÍNGUAS DE IMIGRAÇÃO*
}

\author{
"ELLOS DICEN MUCHAS COSAS MAL PORQUE TIENEN ESA MEZCLA CON LA LENGUA ALEMANA": \\ VOCES DE LOS PROFESORES SOBRE LA EDUCACIÓN EN CONTEXTOS DE LENGUAS DE INMIGRACIÓN \\ "MANY THINGS THEY SPEAK WRONGLY BECAUSE THERE IS THIS MIX OF THE GERMAN LANGUAGE": \\ TEACHERS' VOICES ABOUT THE EDUCATION IN CONTEXTS OF IMMIGRATION LANGUAGES \\ Maristela Pereira Fritzen** \\ Jaqueline Ristau \\ Universidade Regional de Blumenau - FURB, BR
}

\begin{abstract}
RESUMO: Neste artigo pretende-se socializar resultados parciais de uma pesquisa de base interpretativista que objetivou investigar o posicionamento de professores que atuam na educação básica em relação aos contextos bi/multilíngues da região do Vale do Itajaí, SC. A pesquisa teve como principal instrumento entrevistas semiestruturadas. A análise dos registros orientou-se pelo viés teórico da Linguística Aplicada e dos Estudos Culturais. Os registros sugerem que algumas das professoras entrevistadas demonstram reconhecimento do bilinguismo do grupo social onde a escola se insere. Em contraposição, desvela-se em alguns depoimentos o papel da escola em ensinar apenas a língua majoritária do país, em detrimento das línguas de imigração. Os dados também sinalizam um conflito de identidade vivido pelo professor como sujeito falante de uma língua minoritária e, ao mesmo tempo, sujeito professor. Esse conflito parece ressoar as políticas de nacionalização do ensino, que contribuíram para a construção e manutenção do mito do monolinguismo no Brasil.
\end{abstract}

PALAVRAS-CHAVE: bilinguismo social; línguas de imigração; escolarização; identidade.

RESUMEN: En este artículo se pretende socializar los resultados parciales de un estudio de posicionamiento interpretativo que tuvo como objetivo investigar a los docentes que trabajan en la educación básica en relación con los contextos bi/multilingües de la región del Valle de Itajaí, Santa Catarina (Brasil). La investigación tuvo como principal instrumento entrevistas semiestructuradas. El análisis de los registros fue guiado por el sesgo teórico de la Lingüística Aplicada y los Estudios Culturales. Los registros indican que algunas de las profesoras entrevistadas demuestran reconocimiento del bilingüismo del grupo social en el que se encuentra la escuela. No obstante, se revela también en algunos testimonios el papel de la escuela de enseñar solamente la lengua mayoritaria del país, en detrimento de las lenguas de inmigración. Los datos también indican un conflicto de identidad vivido por el profesor como sujeto hablante de una lengua minoritaria y, al mismo tiempo, sujeto profesor. Este conflicto parece resonar las políticas de nacionalización de la educación, las cuales contribuyeron a la construcción y mantenimiento del mito de monolingüismo en Brasil.

PALABRAS-CLAVE: bilingüismo social; lenguas de inmigración; escolarización; identidad.

ABSTRACT: In this article we intend to socialize partial results of a survey of interpretive base that aimed to investigate the positioning of teachers working in basic education in relation to the bi/multilingual contexts from the region of Vale do Itajaí, SC. The survey primarily used semistructured interviews as the main instrument. The analysis of the registries was guided by the theoretical bias of Applied Linguistics as well as Cultural Studies. The registries suggest that some of the interviewed teachers demonstrated recognition in relation to the bilingualism of the social group where the school is located. In contraposition, we realized from some of the statements that the role of schools is teaching only the majority language of the country, to detriment of the immigration languages. The data also indicated a conflict of identity experienced by the teacher as a speaker subject of a minority language and, at the same time, as a teacher subject. This conflict seems to resonate the policies of nationalization of education, which contributed to the construction and maintenance of the myth of monolingualism in Brazil.

KEYWORDS: social bilingualism; immigration languages; education; identity.

\section{INTRODUÇÃO}

As Diretrizes Curriculares Nacionais para a Educação Básica (BRASIL, 2010), ao estabelecer os rumos para a Educação Infantil, o Ensino Fundamental e Médio, recuperam os objetivos constitucionais que pressupõem, entre outros direitos, o direito à igualdade, à pluralidade e à diversidade. No Capítulo II, o

\footnotetext{
* Parte dos dados discutidos neste artigo foi apresentada no XX Seminário do CELLIP, em Londrina, PR, em 2011.

** Email: mpfritzen@gmail.com.
} 
documento prevê que a formação de crianças, jovens e adultos passe pelo estudo dos aspectos que caracterizam o contexto regional e local, entre eles, a cultura.

Não é de hoje, como lembra Cavalcanti (2011), que o discurso da pluralidade e da diversidade está presente em documentos oficias da educação nacional (vide os Parâmetros Curriculares Nacionais, 1997, 1998). A relação do global com o local em práticas sociais envolvendo a linguagem também faz parte desses documentos de parametrização (vide Orientações Curriculares Nacionais para o Ensino Médio, 2008). No entanto, quando se desloca o olhar para cenários interculturais e plurilinguísticos no Brasil e, mais especificamente, quando as lentes focalizam a Educação Básica nesses cenários, o discurso da heterogeneidade cultural, sociolinguística e da inclusão dá lugar a incertezas, conflitos e, não raro, posicionamentos etnocêntricos.

Embora reconheçamos o avanço de tais documentos, consideramos a necessidade de pesquisar, discutir e problematizar a educação em contextos de grupos minoritários e/ou minoritarizados ${ }^{1}$, a fim de dar visibilidade às complexas relações que se estabelecem quando num mesmo espaço social coexistem diferentes línguas. O contato linguístico tem gerado, consequentemente, conflitos linguísticos, identitários, políticos e ideológicos.

Nos últimos anos, temos nos dedicado a pesquisas em um cenário de imigração no Sul do Brasil, onde ainda estão presentes as línguas alemã, italiana e polonesa. Temos procurado desvelar práticas sociais de letramento de indivíduos descendentes de alemães e italianos, interrompidas durante a Campanha de Nacionalização do Ensino (1937-1945) (FRITZEN, 2013); buscado compreender as construções identitárias desses grupos e a educação que vem sendo oferecida a crianças que ainda convivem com a língua de herança familiar (FRITZEN, 2008, 2011; FRITZEN, EWALD, 2011). Neste artigo, nosso propósito é contribuir para esse debate, socializando e discutindo dados parciais de uma pesquisa de cunho interpretativista (ERICKSON, 1986) que teve como objetivo compreender o posicionamento de professores que atuam no Ensino Fundamental em relação aos contextos bi/multilíngues em que se inserem.

Para tanto, organizamos o texto em três seções. Inicialmente, discutimos o mito do monolinguismo no Brasil e sua relação com o contexto da pesquisa aqui relatada. Em seguida, damos voz às professoras, sujeitos de nossa pesquisa, a fim de problematizarmos questões relacionadas ao bilinguismo social, às atitudes linguísticas e às línguas no contexto escolar. Por fim, discutimos as implicações do cenário intercultural para a educação de crianças de grupos minoritários e para a formação de professores.

\section{DO MITO DO MONOLINGUISMO À PLURALIDADE LINGUÍSTICA: CAMINHOS A SEREM PERCORRIDOS NA EDUCAÇÃO DE GRUPOS MINORITÁRIOS}

Conforme mencionado na introdução deste artigo, o discurso da diversidade, do respeito às diferenças, sejam elas de gênero, etnia, sexualidade, tem gerado documentos oficiais importantes na área de educação no País. Parece que se tornou politicamente incorreto levantar a bandeira da homogeneidade, do monoculturalismo, mesmo que ainda persistam, de diferentes formas, noções essencialistas de cultura e identidade. No entanto, nem sempre esses discursos da diversidade ecoam e ressoam de forma positiva nas escolas de Educação Básica ou, muitas vezes, eles chegam nesses contextos de forma enviesada. Basta refletir sobre o episódio do livro didático "Por uma vida melhor", ocorrido em 2011. A imprensa brasileira provocou polêmica ao divulgar parte de conteúdos tratados nesse livro didático de Língua Portuguesa, aprovado pelo Programa Nacional do Livro Didático do MEC (PNLD). Os debates reuniram e confrontaram, nem sempre em mesma proporção, vozes de jornalistas, gramáticos, linguistas ${ }^{2}$, educadores, repercutindo na sociedade em geral.

A análise parcial e equivocada da mídia, por legitimar apenas um padrão idealizado de língua, mostrou, entre outros aspectos, atitudes com relação à não aceitação da variação linguística do português do Brasil.

1. Cavalcanti $(1999,2011)$ argumenta que, ao lado dos contextos minoritários, nos quais estão presentes línguas indígenas, de imigração ou a Libras, por exemplo, há contextos "apresentados como minoritários na sociedade quando, na verdade, são majoritários" (2011, p. 172). Ver discussão adiante sobre o português no Brasil.

2Na ocasião, a Alab (Associação de Linguística Aplicada do Brasil) posicionou-se diante da polêmica, criticando a falta de compreensão da mídia e, consequentemente, da população em geral sobre a atuação do linguista. Da mesma forma, outras associações e estudiosos da linguagem se manifestaram na mídia e reuniram um dossiê que circulou pela internet. 
Falas de determinados grupos sociais minoritarizados, vistas como expressões corrompidas da língua, foram estigmatizadas e alvo de duras críticas. Esse fato revela, de alguma forma, o poder da escrita em detrimento da oralidade, uma vez que vivemos numa sociedade grafocêntrica. As práticas de letramento de instituições reconhecidas socialmente, com frequência, são mais valorizadas que as práticas orais ocorridas na esfera familiar, por exemplo. Além disso, o episódio chama a atenção para forças centrípetas que atuam para impor e fortalecer a língua de poder e prestígio, em detrimento do multilinguismo3.

A atenção da mídia para o tema e os desdobramentos dessa discussão brevemente ilustrados acima deixam claro que tratar de fenômenos linguísticos envolve não apenas a dimensão linguística em si mesma, mas, entre outras, questões históricas, ideológicas, identitárias e de poder. Por esse motivo, afirmar que a língua oficial do Brasil é o português ou que no Brasil se fala português não pode ser feito de forma ingênua, especialmente no espaço da educação formal.

Se hoje parece natural que a língua do Brasil seja o português, ou o 'português brasileiro' (BAGNO, 2001; PERINI, 2010), isso não se deu sem conflitos e coerções. Os primeiros movimentos destinados a eliminar o plurilinguismo brasileiro e promover a língua portuguesa como língua única foram direcionados contra as línguas indígenas (CAVALCANTI, 1999). Mais tarde, por meio de duas campanhas4 de nacionalização do ensino, em especial a segunda, promovida pelo governo de Getúlio Vargas durante o Estado Novo, as línguas de imigração sofreram repressão violenta durante anos nas escolas e outros espaços sociais5. Conforme Seyferth (1981, p. 307), a proibição das línguas dos imigrantes dos países do Eixo (Alemanha, Itália e Japão) pretendia “abrasileirar os 'quistos étnicos', inclusive usando a força” (grifos no original).

Muitos estudos têm denunciado o mito do monolinguismo no Brasil (vide, entre outros, CAVALCANTI, 1999, 2011; BORTONI-RICARDO, 2005). Embora prevaleça essa ideologia do monolinguismo, o bilinguismo, aqui entendido como "a capacidade de fazer uso de mais de uma língua" (MAHER, 2007, p.79), sempre esteve presente no País.

A Sociolinguística, em geral, é disciplina presente no currículo de cursos de formação de professores. No entanto, parece que ainda se discute pouco a diversidade sociolinguística e cultural do País. Ou, quando a diversidade entra na agenda de instituições sociais oficiais, entre elas a escola, não raro, surge de forma estereotipada, com apelos ao curioso e ao exótico6. No caso do contexto de línguas de imigração, as diferentes etnias que colonizaram o Sul do Brasil são representadas em festas típicas, quando expressões culturais como a música, a dança, as comidas são mostradas na mídia, em geral com o objetivo de atrair o turismo. A Oktoberfest em Blumenau pode ser um bom exemplo dessa representação da diversidade 7.

A fim de compreendermos a composição do cenário da região do Vale do Itajaí, foco deste artigo, é preciso lembrar que, por razões históricas e políticas, reuniram-se num mesmo espaço geográfico grupos étnicos diversos, com sua língua, sua crenças, seus comportamentos e modos de construir sentidos às suas ações e ao contexto em que se inserem. O fator principal desencadeador da formação desse contexto intercultural foram as políticas de imigração do País no século XIX, que estimularam o ingresso de imigrantes estrangeiros com o objetivo de povoar terras ditas devolutas, consideradas adequadas à instalação de agricultores livres e europeus (SEYFERTH, 1999).

A Colônia Blumenau no Vale do Itajaí, SC, foi fundada em 1850 e se tornou uma importante colônia alemã da América Latina. Em termos numéricos, os alemães ficaram aquém de imigrantes vindos da Itália, Espanha e Portugal8. Sua importância, porém, dentro do contexto imigratório brasileiro, está relacionada

\footnotetext{
3 Cesar e Cavalcanti (2007, p. 62) sugerem que, nas escolas brasileiras, deveriam ser esquecidas as "dicotomias língua e variedade, língua e norma, língua e dialeto" a fim de tratar o fenômeno da variação dialetal como multilinguismo. (grifos no original)

4. A primeira campanha de nacionalização foi empreendida a partir de 1911 (LUNA, 2000).

5 Fáveri (2005) fez um trabalho exaustivo sobre a Segunda Guerra Mundial e seus efeitos para os imigrantes de alemães e italianos em Santa Catarina.

6 Maher (2007, p. 83) chama a atenção para o fato de que "amostras episódicas de manifestações culturais não são suficientes para garantir o respeito ao plurilinguismo cultural na escola”. Também Silva (2006) critica a abordagem superficial das diferentes culturas no currículo escolar.

7 Para aprofundar essa visão sobre a Oktobesfest em Blumenau, vide Wolff e Flores (1994).

8 Segundo Cavalcanti (1999, p. 390-391), os primeiros portugueses e os africanos não são vistos como imigrantes. Aqueles "parecem ter um status superior como 'donos/donatários' das terras”, enquanto estes, cerca de 6 milhões de pessoas que serviram como mão de obra escrava, foram a razão da adoção de uma política de "branqueamento", em favor da imigração europeia.
} 
com o povoamento dos três estados do Sul, "em zonas pioneiras, constituindo uma sociedade culturalmente diversa” (id. ibid., p. 275).

Os imigrantes alemães formaram na região e no Sul do Brasil (vide KREUTZ, 2003; KORMANN, 1995) um amplo e sólido sistema de ensino9 em função da falta de escolas públicas. Até 1940, o alemão, como língua de imigração, era língua de prestígio, utilizada em práticas de letramento em esferas públicas (imprensa, religião, esfera literária), ensinada nas escolas e presente como língua de interação social, apesar de nunca ter recebido o estatuto de língua oficial.

Como citado anteriormente, o alemão não é a única língua de imigração falada na região. A vinda de outros imigrantes europeus reuniu ainda grupos de fala italiana e polonesa, presentes ainda hoje, embora em número menor 10. Vale lembrar ainda as línguas indígenas faladas na região. Assim, o cenário da pesquisa pode ser considerado "sociolinguisticamente complexo", como tem caracterizado Cavalcanti (1999, 2011) contextos em que estão presentes o português e suas variedades e outras línguas minoritárias ou minoritarizadas, que disputam espaço e poder. No caso de comunidades bilíngues (alemão/português) de Blumenau, ao lado do português padrão, que com frequência tem entrada pela escola, fala-se uma variedade específica do português, com marcas do alemão, além do alemão do grupo e o padrão. A partir de políticas linguísticas recentes, crianças de grupos teuto-brasileiros têm tido acesso a práticas de letramento em alemão padrão nas aulas de Alemão. É importante ainda mencionar que a igreja, no caso dessas comunidades bilíngues, a Igreja Evangélica Luterana, tem um papel relevante como agência de letramento que contribui para a manutenção da língua de herança desses grupos sociais (FRITZEN, 2007).

Na esfera educacional, têm surgido iniciativas importantes com relação à adoção de políticas linguísticas locais em favor de línguas de imigração. No município de Pomerode, cidade vizinha de Blumenau, a língua alemã é disciplina curricular do sistema municipal a partir do primeiro ano do Ensino Fundamental. Além disso, duas escolas públicas municipais oferecem educação bilíngue a partir do primeiro ano escolar desde 2008. Em Blumenau, escolas municipais oferecem a língua alemã, ao lado do inglês, a partir do $4^{\circ}$. ano do Ensino Fundamental 11.

Por outro lado, se levarmos em conta (i) as campanhas de nacionalização do ensino, em especial a empreendida durante o governo Vargas (1937-1945), que impuseram o silenciamento dos falantes de línguas de imigração; (ii) o papel da escola como instrumento de repressão e imposição de uma única língua e uma única cultura e a consequente estigmatização das línguas minoritárias, que prevaleceram em grande parte apenas na oralidade; (iii) o pouco conhecimento dos contextos bi/multilíngues ainda presentes em muitas regiões do Brasil e (iv) a falta de formação de professores para atuarem nesses contextos, chegaremos à conclusão de que ainda há muito a ser feito em favor da "valorização das diferenças e o atendimento à pluralidade e à diversidade cultural, resgatando e respeitando as várias manifestações de cada comunidade", conforme apregoam as Diretrizes Curriculares Nacionais para a Educação Básica, em seu Artigo $9^{\circ}$. (BRASIL, 2010).

\section{3 “A GENTE TEM QUE SE POLICIAR PRA NÃO FALAR EM POLONÊS”: VOZES DE PROFESSORAS EM CONTEXTOS DE LÍNGUAS DE IMIGRAÇÃO}

A partir de entrevistas semiestruturadas ${ }^{12}$, professoras do Ensino Fundamental da região do Médio Vale do Itajaí foram convidadas a manifestar seu ponto de vista com relação às línguas de imigração mantidas no contexto onde atuam, com relação aos seus falantes, bem como ao seu posicionamento diante da educação

\footnotetext{
9 Luna (2000) chama a atenção para o fato de que desde o reinado de Frederick II (entre 1740 e 1786) já era obrigatória a frequência à escola no sistema escolar alemão.

10 Seria difícil hoje estimar o número de pessoas em Blumenau e Vale do Itajaí que ainda falam alguma língua de imigração e que a mantém em suas relações familiares e sociais. Segundo Oliveira (2002, p. 88), "de todos os censos brasileiros, somente os de 1940 e 1950 se interessaram por perguntar qual língua os brasileiros usavam no lar, e se sabiam falar português”. O censo de 2010 incluiu, para a população indígena, pergunta com relação à etnia ou povo a que pertence e à língua falada. No caso das antigas zonas de imigração, não há dados oficiais sobre as línguas ainda faladas hoje, salvo por iniciativas de pesquisadores.

11 Há no município 50 escolas públicas, entre elas, sete multisseriadas, situadas em zonas rurais. Dessas 50, 20 oferecem o ensino da língua alemã. 
oferecida a crianças membros desses grupos. Levando em consideração o espaço de discussão deste artigo, selecionamos quatro entrevistas para discussão.

Os primeiros trechos a seguir são depoimentos da professora Ana ${ }^{13}$, teuto-brasileira ${ }^{14}$ e pedagoga, que trabalha há nove anos como professora de Língua Alemã e segue uma rotina de cinquenta horas/aula em escolas municipais de Blumenau, SC.

Quanto às escolhas linguísticas no ensino, as escolas municipais de Blumenau possuem em seu currículo as disciplinas de Língua Alemã e de Língua Inglesa. Os alunos, do quarto ao nono ano, têm uma aula de Língua Inglesa e uma aula de Língua Alemã por semana. Algumas escolas, visando maior aprendizado dos alunos, desenvolvem projetos extraclasses, como o "Clube do alemão" no contraturno, que, conforme a professora Ana, já conseguiu resultados satisfatórios, como a aplicação da prova do Instituto Goethe de Porto Alegre, que certifica na língua alemã o aluno aprovado no exame.

Durante a entrevista, Ana comentou sobre a escola multisseriada na qual também é professora de Língua Alemã:

\begin{abstract}
Ana $^{15}$ : então, eu ocupando a língua mãe deles [alunos] que eles falam em casa eles me entendem com mais facilidade do que aquela que eles usam normalmente na escola e no corredor da escola e tudo mais $(++)$ então a gente fala basicamente só alemão né então assim, $(+)$ tanto que nessa escola todos os professores praticamente sabem falar alemão né $(+)$ entendem alemão né’ (+) já é pra eles muito bom porque o problema é quando você tem uma turma que se explicar alguma coisa em português ela não entende e se você não conseguir passar um movimento na língua que ela entenda é complicado né' então ela vai ficar muitas vezes defasada naquele conteúdo (+) então estamos bem felizes que a gente tem professores que conseguem também auxiliar os alunos na língua alemã também $(+)$ não só quando eu estou mas durante a semana toda /.../
\end{abstract}

Nessa escola, localizada em zona rural do município, as crianças ainda aprendem a falar alemão com a família. O fato de os professores também serem teuto-brasileiros e poderem usar a língua do aluno, em algumas situações, como língua de instrução na escola, é destacado pela professora. Ela afirma: o problema quando você tem uma turma que se explicar alguma coisa em português e ela não entende. Essa é a situação de muitos alunos que ainda hoje entram na escola falando predominantemente o alemão e não encontram na educação formal apoio para sua língua, pois, embora a língua de imigração tenha entrado no currículo escolar como uma disciplina, a língua de instrução oficial é o português.

A professora Beatriz, pedagoga, que não fala nenhuma das línguas de imigração presentes na região e atua como professora na educação infantil no município de Blumenau, conta suas experiências que remetem à situação problema relatada pela professora Ana:

Entrevistadora: a que você associaria língua alemã?

Beatriz: Alemanha

Entrevistadora: Alemão?

\footnotetext{
13 Para nomear as professores, sujeitos da pesquisa, são usados pseudônimos a fim de preservar sua identidade.

14 Estamos compreendendo aqui “teuto-brasileira/o" como um qualificativo para nos referirmos a descendentes de imigrantes alemães, da terceira, quarta ou quinta geração, que ainda aprenderam em casa a língua de herança familiar.

15 Convenções de transcrição adaptadas de Marcuschi (1986):

$(+)$ cada sinal indica pausas pequenas de 0.5 segundo

/.../ indica que parte da fala foi omitida

:: indica prolongamento de som precedente

'para uma subida leve (como uma vírgula)

, descida leve ou brusca
}

MAIÚSCULA indica ênfase 
Beatriz: /.../ a região das /.../ [cita um bairro $](+)$ se tu ir aqui pra /.../ [cita o mesmo bairro $]$, todo mundo fala SUPER ALEMAO (+) aí eu dou aula na [menciona a escola], ninguém fala, foi bem difícil eu vir pra cá porque quando eu cheguei aqui eles falavam errado muitas coisas eles falam errado porque tem essa mistura da língua alemã né” $(+)$ NOSSA me assustei né” $(+)$ aí tu vai ali na [menciona escola] $(+)$ lá também’ é regiões alemãs que assim ó: a gente percebe LOgo porque o errado que eles falam $(+)$ porque se tu dá aula no /.../[cita outro bairro] tu não vê ninguém falando a origem alemã

Ao refletir sobre a palavra 'alemão' e ao buscar associações livres com outras ideias, a professora demonstra seu estranhamento ao se deparar com um contexto diferente do que estava acostumada a viver e a atuar como professora (nossa me assustę). O posicionamento de Beatriz é também uma atitude muito presente na região, nos discursos que circulam em diferentes esferas (vide, entre outros, FRITZEN, 2007; MAILER, 2003), pois as comunidades que ainda usam o alemão como língua de interação são invisibilizadas e sua língua, não raro, estigmatizada.

Ao relacionar a palavra 'alemão' com outras palavras, Beatriz relata sua experiência ao chegar a uma escola rural e compara os usos linguísticos de seus alunos na comunidade teuto-brasileira na qual trabalha com outros bairros do município onde a língua alemã não parece mais presente. A professora demonstra uma visão de língua pura, uniforme, sem variações. Uma língua "misturada", com marcas de outra língua não poderia ser considerada "correta" nessa visão (falam errado porque tem essa mistura da língua alemã). Parece que a "língua alemã" é 'a' língua falada na Alemanha ${ }^{16}$, conforme a associação da professora. A língua alemã falada pela comunidade onde Beatriz atua não poderia ser denominada como tal. Embora a língua, [...] "na concepção dos sociolinguistas, é intrinsecamente heterogênea, múltipla, variável, instável e está sempre em desconstrução e reconstrução" (BAGNO, 2007, p. 36), essa perspectiva teórica ainda não encontra ressonância para se compreender o contex to plurilinguístico local.

Quando procuramos saber como foi sua experiência nessa comunidade teuto-brasileira, a professora Beatriz assim se pronunciou:

Beatriz: vou falar de um aluno de pré que sempre falaram em alemão com ele em casa e assim: nossa' nosso contato foi difícil porque eu não/ eu não entendia nenhuma palavra do que ele falava e E::le não entendia o que eu falava, /.../ daí ele vinha pedir ai professora eu queria uma coisa (++) ele falava alemão, daí eu tinha que ter um intermediário que a:: coordenadora na época ela falava pra mim e daí eu entendia tudo bem, mas olha que difícil, /.../ a situação na escola também era complicada porque era todo mundo alemão $(+)$ ai tu vai, tu é morena, tu vai trabalhar numa escola dessas, tu tem uma rejeição $(+)$ acredita que houve uma rejeição entre os funcionários entre a coordenação, direção porque todo mundo falava em alemão na hora do café” eu era a ÚNICA que não entendia, mas era uma escola mais isolada aqui na /.../ [cita o bairro] né" (+) eu tô contando uma escola mais isolada lá, mas assim bem complicado a língua alemã a gente não entender nada /.../

Beatriz recorda de um caso de um aluno seu que entrou na escola falando a língua de herança familiar. Ela descreve sua dificuldade em se comunicar com ele e que estratégias usou para dar conta da interação com esse aluno. $\mathrm{O}$ fato de haver outras pessoas na escola (a coordenadora na época ela falava pra mim) que também dominavam o alemão facilitou a inserção do aluno nas práticas escolares. Certamente para o aluno a experiência também deve ter sido difícil. Beatriz expõe ainda sua posição de outsider em relação ao grupo, ao ter sentido rejeição por parte dos demais colegas, porque todo mundo falava em alemão na hora do cafée. Sem ter a intenção de justificar o uso da língua alemã na hora da pausa, talvez seja bom lembrar que, se a escola se inseria numa comunidade bilíngue (alemão-português), se as demais professoras e gestoras também pertenciam ao grupo teuto-brasileiro, certamente é natural que a língua de interação tenha sido/seja preferencialmente o alemão. No entanto, a rejeição sentida por Beatriz vai além de sua impossibilidade de fazer parte das conversas dos colegas na hora da pausa, mas passa também pela sua aparência física: porque era todo mundo alemão (+) ai tu vai, tué morena (...).

Esse depoimento da professora nos leva a refletir sobre a questão das identidades culturais. Beatriz se choca com o multilinguismo encontrado na escola, se sente ao mesmo tempo rejeitada por não dominar a língua do grupo social onde se insere e pela sua aparência física. Não é de hoje que a escola é um lugar de heterogeneidade, de diversidade, um lócus que tem reunido diferentes, embora nem sempre as diferenças tenham sido mostradas e reconhecidas. Na sociedade atual e invariavelmente também na escola, esse

16 É preciso lembrar que não há apenas uma língua alemã, mas línguas em alemão, parafraseando José Saramago, que afirmou: “quase me apetece dizer que não há uma língua portuguesa, há línguas em português”. (O depoimento foi registrado no filme "Língua: vidas em português”, dirigido por Victor Lopes e divulgado no Brasil em 2004). 
encontro com o outro, com o diferente, é inevitável (SILVA, 2006). Não apenas inevitável, mas esse confronto com o outro é necessário, pois é por meio dele que construímos e projetamos nossas identidades. Nem sempre, porém, esse encontro ocorre sem conflitos.

A experiência relatada pela professora Beatriz aponta para a complexidade do contexto escolar em zonas de imigração como este foco da pesquisa aqui relatada. Vale lembrar os PCNs como um dos documentos oficiais que, já em 1997, chamavam a atenção para a necessidade de a educação possibilitar uma compreensão ampla do contexto sociocultural do País. Entre os objetivos para o ensino fundamental, o documento sustenta que a educação deve oportunizar ao indivíduo "conhecer e valorizar a pluralidade do patrimônio sociocultural brasileiro, bem como aspectos socioculturais de outros povos e nações, posicionando-se contra qualquer discriminação baseada em diferenças culturais, de classe social, de crenças, de sexo, de etnia ou outras características individuais e sociais” (BRASIL, 1997, p. 66).

Parece mais simples abordar a pluralidade sociocultural do País no currículo escolar quando se apelam para modelos estereotipados e puros, como vêm sendo tratados em geral os povos indígenas (vide, entre outros, OLIVEIRA, 2003; MAHER, 1996). Do mesmo modo, falar em diferenças culturais soa mais brando quando elas se situam longe, como exemplos de outros. Quando, porém, a própria escola e a comunidade onde ela se insere constituem laboratórios práticos, lócus da diversidade, nem sempre as diferenças são percebidas ou vistas como questões a serem discutidas. Muitos conflitos advindos das diferenças interculturais e dos posicionamentos de identidades culturais passam à margem da agenda escolar. Acreditamos que um dos motivos para isso reside na própria formação de professores 17 que, como já argumentamos acima, ainda se sustenta no que Oliveira (2002) chama de "Sociolinguística do monolinguismo".

Se, por um lado, os atores sociais que convivem nesse espaço escolar deveriam "conhecer e valorizar o patrimônio sociocultural brasileiro” - reafirmando os PCNs -, a fim de evitar a discriminação, por outro lado, seria necessário desenvolver atitudes de respeito e de tolerância para com o outro. Um passo além, igualmente necessário, seria incluir na agenda dos conteúdos escolares a discussão sobre a produção da identidade e da diferença, conforme argumenta Silva (2006).

Em outro contexto próximo desse da professora Beatriz, na cidade de Pomerode 18, SC, encontramos a professora Ingrid, a qual aprendeu a língua alemã juntamente com a língua portuguesa na esfera familiar. Ela é professora de Alemão em uma das escolas da rede de ensino municipal que oferece educação bilíngue a partir do primeiro ano do ensino fundamental. No excerto a seguir ela explica como desenvolveu ambas as línguas.

Entrevistadora: como aluna você ingressou na escola falando que língua?

Ingrid: português, português /.../ eu aprendi o alemão junto com o português (+) eu assim não me lembro de falar só alemão em casa (+) tinha vizinhos assim que falavam português e eu brincava muito assim com eles então eu não fui aquela criança que teve a língua materna o alemão né foram os dois simultâneos assim $(++)$ então é diferente de outras pessoas que falavam alemão e aprenderam português só na escola e se sentiram um pouco constrangidas porque não sabiam interagir na escola porque não tinham o português

Entrevistadora: você ainda fala a língua que aprendeu em casa?

Ingrid: procuro falar com meus pais né' (+) minha avó alguns tios que falam e quando a gente encontra alguém que fala alemão a gente procura preservar e tentar falar alemão, /.../

$\mathrm{Na}$ fala da professora Ingrid é possível destacar o aprendizado da língua alemã com a família e o contato através da língua portuguesa com os vizinhos, o que, mais tarde, facilitou seu ingresso e comunicação na escola. Ingrid menciona a experiência vivenciada por muitos teuto-brasileiros que entram na escola sem saber falar o português. Esse "constrangimento" pode se relacionar tanto ao fato de a comunicação se tornar "difícil”, conforme mencionado pela professora Beatriz, como também pode soar como reminiscências do

17 Ainda que a discussão sobre o português e as variedades linguísticas já esteja em geral presente na matriz curricular e ementas das disciplinas nos cursos de Letras e Pedagogia, seus efeitos positivos ainda repercutem pouco na escola, como pôde ser visto no episódio do livro relatado na segunda seção.

18 O município de Pomerode fazia parte da então Colônia Blumenau e do município de Blumenau até 1958. No sistema de ensino municipal, como mencionamos anteriormente, há duas escolas que oferecem um Programa de Educação Bilíngue desde 2008. A professora entrevistada trabalha nesse Programa. 
período da campanha de nacionalização do ensino, em que as línguas de imigração foram proibidas, especialmente no ambiente escolar. Para os que não tinham ainda adquirido o português, só restou o silenciamento.

Uma das consequências das políticas de nacionalização pode ser depreendida da fala da professora quando comenta o contato que mantém com a língua alemã em sua família: procuro falar com meus pais né’ (+) minha avó alguns tios que falam e quando a gente encontra alguém que fala alemão a gente procura preservar e tentar falar alemão. Conforme citado anteriormente, com as campanhas de nacionalização, a língua alemã, de língua de prestígio, passou a língua proibida, estigmatizada, 'língua de colono', num sentido pejorativo do termo. Com a interrupção das práticas de letramento em alemão, inclusive na esfera familiar, em virtude do confisco de livros e materiais em língua alemã, o alemão passou à língua oral. Se hoje a professora Ingrid ainda pode utilizar a língua de imigração com seus familiares é porque houve movimentos de resistência à imposição do português como língua única, oficial. A atitude de Ingrid, professora de Alemão, em buscar “preservar” essa língua, demonstra a valorização da língua do seu grupo étnico e o intuito de mantê-la viva.

Entrevistadora: a que você associa imigrante?

Ingrid: associo a nossa escola né’, que foi é:: a gente estudou bastante agora sobre os colonizadores que trouxeram né essa cultura lá da Alemanha que em Pomerode é: isso bastante forte desbravaram, como se falava aqui $(++)$ trouxeram assim bastante trabalho né' eles suaram a camisa pra conseguir tudo o que conseguiram né tiveram bastante sofrimento muitas lutas né' se desprenderam lá da sua Alemanha querida né sua terra natal pra vir pra uma país diferente totalmente diferente né’ que eles tinham lá pra batalhar mesmo por um futuro que eu penso que era pros filhos deles ao mesmo tempo já pensavam nos netos e daí a gente também pensa assim né fazer o melhor para os nossos filhos nossos futuros netos né' e acho que essa corrente vai de geração em geração pro melhor né',

Em seu depoimento, Ingrid ressalta o trabalho dos primeiros imigrantes alemães na colonização da região e manifesta sentimento de solidariedade ao grupo teuto-brasileiro. Quando diz a gente estudou bastante agora sobre os colonizadores, demonstra como ela e os demais professores da escola procuram construir conhecimentos relacionados à história local. A professora reconhece as mudanças trazidas à região com a colonização e as manifestações culturais alemãs em sua cidade. Ela tece seu discurso como descendente dos que se desprenderam lá da sua Alemanha querida, projetando sua identidade étnico-linguística teuto-brasileira. As representações que constrói demonstram uma relação positiva com a terra natal dos imigrantes (querida Alemanha), o reconhecimento de seu esforço (desbravaram, suaram a camisa, batalhar) e um sentimento de responsabilidade em dar continuidade ao trabalho já iniciado por eles (fazer o melhor para nossos filhos, nossos futuros netos).

Em seu contexto de trabalho, Ingrid estava tendo sua primeira experiência com uma carga horária maior de aulas sendo lecionadas em Língua Alemã por meio do ensino bilíngue:

Ingrid: /.../ perceber que crianças de/ de um meio assim (+) de uma família que fala alemão conseguem acompanhar isso e:: se interarem comigo enquanto as outras crianças que não têm o alemão em casa $(+)$ onde o pai não fala alemão nem a mãe, mas eles (+) é:: têm aquela ansiedade aquela sede também de conhecer e eles chegam em casa e contam pros pais o que aprenderam e ai:: depois voltam relatos assim de que os pais tão aprendendo com os filhos e que eles tão:: aprendendo junto com aqueles que já sabem um pouco $(++)$ então isso é legal é muito interessante de ver essa esse CRESCIMENTO deles no idioma estrangeiro $(+)$ até mesmo a gente já percebeu que o professor de inglês relatou que melhorou o desempenho deles na língua inglesa $(+)$ também a partir do ensino bilíngue, que a gente aprende um pouco do alemão, o inglês também já favoreceu assim no desenvolvimento da pronuncia, da escrita foi o professor de inglês que nos disse que ele percebeu essa melhora.

Nesse relato, depreendemos que o ensino da língua alemã na escola bilíngue provocou uma mobilização familiar devido ao interesse no aprendizado demonstrado pelas crianças e pelas famílias, mesmo as que não fazem parte do grupo teuto-brasileiro. Ingrid percebe com entusiasmo o "crescimento" do repertório linguístico de seus alunos com o ensino bilíngue. De fato, muitas pesquisas têm sugerido "uma relação positiva entre bilinguismo, funcionamento cognitivo e competência comunicativa” (MAHER, 2007, p. 71). Entre as vantagens citadas na literatura especializada, estão o "aumento do pensamento divergente/criativo, maior predisposição ao pensamento abstrato, maior consciência metalinguística, maior sensibilidade para o contexto de comunicação [...]” (id. ibid, p. 81; vide ainda RIEHL, 2001).

Entrevistadora: você acha que a escola tem algum papel em relação às crianças que ainda aprendem em casa com a família o alemão? 
Ingrid: eu acredito que a escola tem essa responsabilidade de::/ que nem eles têm o dialeto em casa e na escola é diferente tem o alemão padrão, então assim, a gente procura preservar o dialeto deles e:: alguns pais já disseram até que o meu filho veio me falar que eu tô falando tudo errado alemão e a gente procura dizer pros pais se acalmarem que isso é o alemão da escola, alemão padrão que né mas que eles não deixem de falar o alemão deles em casa também porque é um dialeto né' e isso é uma riqueza sem tamanho né" eles terem esses diferentes dialetos $(+)$ na Alemanha, a gente tem muitos dialetos mesmo e isso é muito legal

Nesse excerto, Ingrid relata o confronto entre as línguas alemãs, isto é, a língua aprendida na esfera familiar, que ela define como dialeto, e a língua ensinada na escola, o alemão padrão. Mesmo que a professora denomine a língua aprendida em casa de "dialeto", o que intrinsecamente poderia remeter à ideia de inferioridade com relação ao padrão, o posicionamento da professora é de reconhecimento e de valorização da língua de imigração. Ela procura lidar com o conflito linguístico, enfatizando aos pais e alunos a importância de manterem a sua língua em casa, enquanto na escola as crianças teriam acesso à língua em sua forma padrão. Nesse contexto de bilinguismo de minoria, a língua do aluno e da comunidade é vista de forma positiva, como um bem cultural da região.

Dentre os modelos de educação bilíngue sintetizados por Freeman (1998), de transição, de manutenção e de enriquecimento ${ }^{19}$, podemos aproximar o programa de educação bilíngue desenvolvido em Pomerode ao modelo de enriquecimento, uma vez que visa à aprendizagem da língua minoritária, neste caso do alemão, não apenas aos alunos teuto-brasileiros, mas também às crianças que não fazem parte desse grupo. A língua alemã é vista como um direito e um recurso para toda a sociedade, cabendo à escola promover o bilinguismo de enriquecimento.

No contexto de língua polonesa, entrevistamos a professora Magda, que aprendeu a língua de imigração na esfera familiar. Magda atua na Educação Infantil em uma escola rural multisseriada de Blumenau. A escola conta com aproximadamente trinta alunos de origem polonesa. De acordo com a professora, alguns desses alunos aprenderam o polonês como primeira língua e entraram na escola falando apenas sua língua de herança. Ainda de acordo com a professora, em relação ao caráter socioeconômico, algumas famílias tiveram há pouco tempo acesso à luz elétrica e aparelhos como rádio, televisão.

Entrevistadora: você já trabalha com crianças e adolescentes que são falantes do polonês (+) como é essa experiência?

Magda: como eu disse é uma coisa natural, a vontade e a facilidade em falar em polonês é:: espontânea né" $(+)$ é claro que depois de muitos anos a gente tem que se policiar muito pra não falar em polonês com as crianças que sabem $(++)$ quando elas têm dificuldade em alguma coisa ou dúvidas é mais fácil falar em polonês ou pedir o que elas tão sentindo, onde tá doendo $(+)$ seria bem mais fácil falar em polonês né”, porque elas conseguem se abrir melhor né” porque a língua mãe delas no caso dessas criança que eu tô agora também é o polonês

Magda admite a facilidade em falar em polonês, por ser mais natural, espontâneo, uma vez que ela também fala a língua de herança dos alunos, fazendo parte desse grupo étnico-linguístico. Em seu depoimento, vem à tona o conflito linguístico entre a língua de imigração, o polonês, e o ensino monolíngue, em português, na escola. Como não há uma política linguística local que reconheça o bilinguismo social presente nesse contexto rural, a escola desconsidera a língua dos alunos. Por força do currículo assentado na homogeneização cultural, Magda vive o conflito identitário como professora e como membro do grupo social. Ela se mostra solidária à língua dos alunos (quando elas têm dificuldade em alguma coisa ou dúvidas é mais fácil falar em polonês), mas suas atitudes denotam seu esforço em favor de um ensino monolíngue em português (a gente tem que se policiar muito pra não falar em polonês), que desconsidera as diferenças culturais dos educandos.

Entrevistadora: e você acha que a escola tem algum papel com relação às crianças que ainda aprendem em casa com a família o polonês?

Magda: elas têm obrigação entre aspas de ensinar o português $(++)$ porque elas vivem no Brasil onde falamos o português qualquer lugar que elas vão elas devem falar o português né' comunicação fora de casa né'

19 Uma discussão mais aprofundada sobre os modelos de educação bilíngue é feita em Fritzen (2012). 
Discursos como o de Magda (Brasil onde falamos o português) ainda são muito comuns, em virtude do desconhecimento e da invisibilidade de contextos de grupos minoritários, conforme abordado na seção anterior. Mesmo mostrando-se sensível à língua local, como visto no excerto acima, Magda vê a escola como instituição que tem a obrigação de ensinar a língua majoritária. Parece legítimo esse reconhecimento. No entanto, em sua fala, essa organização do ensino apoiado unicamente no português, com o consequente apagamento das diferenças, não é questionado. Parece que se naturalizou o papel da escola como agência de letramento em favor do monolinguismo e do monoculturalismo. A consequência desse modelo de ensino monolíngue faz alunos/as e a professora abdicarem da língua de seu grupo étnico, renunciarem a sua própria diferença.

Novamente é preciso ressaltar a literatura especializada referente à educação bilíngue que tem argumentado que "quanto maior o investimento pedagógico na língua materna, mais facilidade terá o aluno de se desenvolver em sua segunda língua" (MAHER, 2007, p. 70). Além desse aspecto cognitivo, fundamental para o desenvolvimento e ampliação do repertório linguístico das crianças, podemos afirmar que esse investimento na língua do grupo minoritário por meio da educação formal contribuiria para o fortalecimento das experiências e "conhecimentos locais" (CANAGARAJAH, 2005) e para a melhoria da convivência intercultural.

\section{CONSIDERAÇÕES FINAIS}

Os depoimentos das professoras da Educação Básica do Médio Vale do Itajaí, que atuam em diferentes contextos de línguas minoritárias, fazem-nos refletir sobre a complexidade sociolinguística desses cenários e os desafios que se impõem à educação formal. As línguas de imigração, apesar dos vários anos banidas do currículo escolar, ainda estão presentes em muitos espaços sociais, constituindo parte das identidades culturais dos grupos da região. Se hoje algumas delas retornaram à educação formal, como é o caso do alemão e do italiano ${ }^{20}$, em função de políticas linguísticas locais recentes, isso não significa que as tensões e os conflitos interculturais tenham sido resolvidos. O encontro com o outro cultural, especialmente na esfera escolar, foco deste artigo, se revela sempre uma questão identitária e um problema pedagógico (SILVA 2006).

As vozes das professoras da educação básica desvelam suas inquietações, angústias e suas estratégias para lidarem com a interculturalidade na sala de aula. No caso das professoras membros de grupos minoritários, suas experiências pessoais como alunas ecoam em seu posicionamento como professoras hoje. Embora estejamos lidando com contextos de línguas minoritárias numa mesma região geográfica, os depoimentos apontam para diferenças entre as comunidades, as escolas e as políticas linguísticas públicas. Por isso, o conhecimento do entorno, das experiências e perspectivas locais e, por que não dizer, dos letramentos da comunidade, mostra-se essencial no processo de escolarização.

Nesse sentido, os cursos de formação inicial e contínua de professores poderiam promover um fórum permanente sobre as línguas do Brasil, sobre os contextos de grupos minoritários e/ou minoritarizados, sobre a educação que tem sido oferecida a esses grupos, sobre as construções de identidades culturais. Para tanto, não basta que se adotem listas de termos da Sociolinguística, por exemplo, se não se problematizam de forma efetiva esses conceitos, como têm sido usados em pesquisas e como se relacionam com contextos interculturais reais, muitas vezes tão próximos da própria universidade onde se dá a formação.

Se estivermos convictos de que (i) a educação básica deveria promover, entre outros direitos, o direito à pluralidade linguística e à diversidade, e de que (ii) as línguas de imigração, dos povos indígenas, ao lado do português, são bens culturais da sociedade, precisamos buscar dar voz, em nossas pesquisas, aos atores sociais que diariamente lidam com os conflitos interculturais especialmente na escola. Precisamos insistir em problematizar relações de poder que se instauram na convivência difícil, como lembra Maher (2008), com o outro cultural. Assim, poderemos fornecer subsídios importantes para a adoção de políticas linguísticas locais favoráveis ao reconhecimento das línguas minoritárias, mas, ao mesmo tempo, refletir sobre o tratamento dado a essas línguas e ao português dos grupos de línguas de imigração na escola e na comunidade onde ela se situa.

20 Não entrevistamos professoras que atuam em contexto de língua italiana, mas no município de Rodeio, por exemplo, a língua de imigração faz parte do currículo escolar desde 2001. 


\section{REFERÊNCIAS}

BAGNO, M. Português ou brasileiro: um convite à pesquisa. São Paulo: Parábola Editorial, 2001.

. Nada na língua é por acaso: por uma pedagogia da variação linguística. São Paulo: Parábola Editorial, 2007.

BORTONI-RICARDO, S. M. Nós cheguemu na escola, e agora?: Sociolinguística e educação. São Paulo: Parábola Editorial, 2005.

BRASIL. Parâmetros Curriculares Nacionais - Introdução. Brasília: Ministério da Educação, Secretaria de Educação Fundamental, 1997.

Parâmetros Curriculares para o Ensino Fundamental: terceiro e quarto ciclos do Ensino Fundamental. Brasília: Brasília: Ministério da Educação, Secretaria de Educação Fundamental, 1998.

Orientações Curriculares Nacionais para o Ensino Médio. Brasília, D.F: Ministério da Educação, Secretaria de Educação Básica, 2008.

Diretrizes Curriculares Nacionais para a Educação Básica. Ministério da Educação. Conselho Nacional da Educação. Brasília: MEC, 2010.

CANAGARAJAH, A. S. (Org.). Reclaiming the local in language policy and practice. Mahwah: Erlbaum, 2005.

CAVALCANTI, M. C. Estudos sobre educação bilíngüe e escolarização em contextos de minorias lingüísticas no Brasil. DELTA, v. 15, número especial, 1999, p. 385-418.

. Bi/multilinguismo, escolarização e o (re)conhecimento de contextos minoritários, minoritarizados e invisibilizados. In MAGALHÃES, M. C. C.; FIDALGO, S. S.; SHIMOURA, A. S. (orgs.) A formação no contexto escolar: uma perspectiva crítico-colaborativa. Campinas, SP: Mercado de Letras, 2011. p. 171-185.

CÉSAR, A.; CAVALCANTI, M. Do singular ao multifacetado: o conceito de língua como caleidoscópio. In: CAVALCANTI, M.; BORTONI-RICARDO, S. M. (Orgs.). Transculturalidade, linguagem e educação. Campinas, SP: Mercado de Letras, 2007.

ERICKSON, F. Qualitative methods in research on teaching. In: WITTROCK, M. C. (Org.). Handbook of research on teaching. Londres: Macmilian, 1986. p. 77-200.

FÁVERI, M. Memórias de uma (outra) guerra: cotidiano e medo durante a Segunda Guerra em Santa Catarina. 2. ed. Itajaí: Universidade do Vale do Itajaí; Florianópolis: Universidade Federal de Santa Catarina, 2005.

FREEMAN, R. Bilingual education and social change. Clevedon: Multilingual Matters, 1998.

FRITZEN, M. P. "Ich kann mein Name mit letra junta und letra solta schreiben": bilinguismo e letramento em uma escola rural localizada em zona de imigração alemã no Sul do Brasil. Tese (Doutorado em Lingüística Aplicada) - Universidade Estadual de Campinas, 2007.

. Ich spreche anders, aber das ist auch deutsch: línguas em conflito em uma escola rural localizada em zona de imigração no sul do Brasil. Trabalhos em Linguística Aplicada, Campinas, v.2, n. 47, p. 341-356, jul./dez. 2008.

Reflexões sobre práticas de letramento em contexto escolar de língua minoritária. DELTA. Documentação de Estudos em Linguística Teórica e Aplicada, v. 27, p. 63-76, 2011.

. "Ia na escola alemã e de um dia pro outro fechou. E nós não sabíamos falar o português": refletindo sobre as políticas linguísticas em contexto de língua minoritária. Linguagem \& Ensino, v.15, n.1, p. 113-138, jan./jul. 2012.

. Refletindo sobre a proteção e os direitos linguísticos de grupos de línguas de imigração no Brasil: “Auf Wiedersehen! Eu vou. Fui preso porque eu falei alemão". In JUBILUT, L. L.; MAGALHÃES, J. L. Q.; BAHIA, A. G. M. F. (Orgs.). Direito à diferença e a proteção jurídica das minorias. São Paulo: Saraiva, 2013. (no prelo).

FRITZEN, M. P.; EWALD, L. "Bilíngue? Só seu eu tivesse um curso ou escrevesse diariamente”: considerações sobre bilinguismo e educação em um contexto de línguas de imigração. Atos de pesquisa em educação, v. 6, n. 1, p. 146-163, jan./abr. 2011. 
KORMANN, E. Blumenau: arte, cultura e as histórias de sua gente. Blumenau: Edição da autora, 1995.

KREUTZ, L. Língua de referência na escola teuto-brasileira. In: CUNHA, J.L.; GÄRTNER, A. (Orgs.). Imigração alemã no Rio Grande do Sul: história, linguagem, educação. Santa Maria, RS: Editora da UFSM, 2003. p. 133-157.

LUNA, J. M. F. O Português na Escola Alemã de Blumenau: da formação à extinção de uma prática. "Ensinávamos e aprendíamos a Língua do Brasil". Itajaí: Ed. da Univali; Blumenau: Furb, 2000.

MAHER, T., M. Ser professor sendo índio: questões de lingua(gem) e identidade. Tese (Doutorado em Linguística Aplicada). Universidade Estadual de Campinas, 1996.

. Do casulo ao movimento: a suspensão das certezas na educação bilíngüe e intercultural. In: CAVALCANTI, M.; BORTONI-RICARDO, S. M. (Orgs.). Transculturalidade, linguagem e educação. Campinas, SP: Mercado de Letras, 2007. p. 67-94.

. Em busca de conforto linguístico e metodolótigo no Acre indígena. Trabalhos em Linguística Aplicada, v. 47, n. 2, p. 409-428, jul./dez. 2008.

MAILER, V. C. O. O alemão em Blumenau: uma questão de identidade e cidadania. 2003. Dissertação (Mestrado em Linguística) - Universidade Federal de Santa Catarina, Florianópolis, 2003.

MARCUSCHI, L. A. Análise da conversação. São Paulo: Ática, 1986.

OLIVEIRA, G. M. Brasileiro fala português: monolinguismo e preconceito linguístico. In: MOURA e SILVA (Orgs.). O direito à fala: a questão do preconceito lingüístico. Florianópolis, SC: Editora Insular, 2002.

OLIVEIRA, T. S. Olhares que fazem a "diferença": o íncio em livros didáticos e outros artefatos culturais. Revista Brasileira de Educação, n. 22, p. 25-34, jan./abr. 2003.

PERINI, M. A. Gramática do português brasileiro. São Paulo: Parábola Editorial, 2010.

RIEHL, C. M. Schreiben, Text und Mehrsprachigkeit: zur Textproduktion in mehrsprachigen Gesellschaften am Beispiel der deutschsprachigen Minderheiten in Südtirol und Ostbelgien. Tübingen: StauffenburgVerlag, 2001.

SEYFERTH, G. Nacionalismo e identidade étnica. Florianópolis: Fundação Catarinense da Cultura, 1981.

. A colonização alemã no Brasil: etnicidade e conflito. In: FAUSTO, B. (Org.). Fazer a América. São Paulo: USP, 1999. p. 273-313.

SILVA, T. T. A produção social da identidade e da diferença. In: SILVA, T. T. (Org.). Identidade e diferença: a perspectiva dos estudos culturais. 6. ed. Petrópolis: Vozes, 2006. p. 73-102.

WOLFF, C. S.; FLORES, M. B. R. A Oktoberfest de Blumenau: turismo e identidade étnica na invenção de uma tradição. In: MAUCH, C.; VASCONCELLOS, N. (Org.). Os alemães no sul do Brasil: cultura, etnicidade e história. Canoas: Ed. ULBRA, 1994.

Recebido em 11/11/13. Aprovado em 19/12/13. 